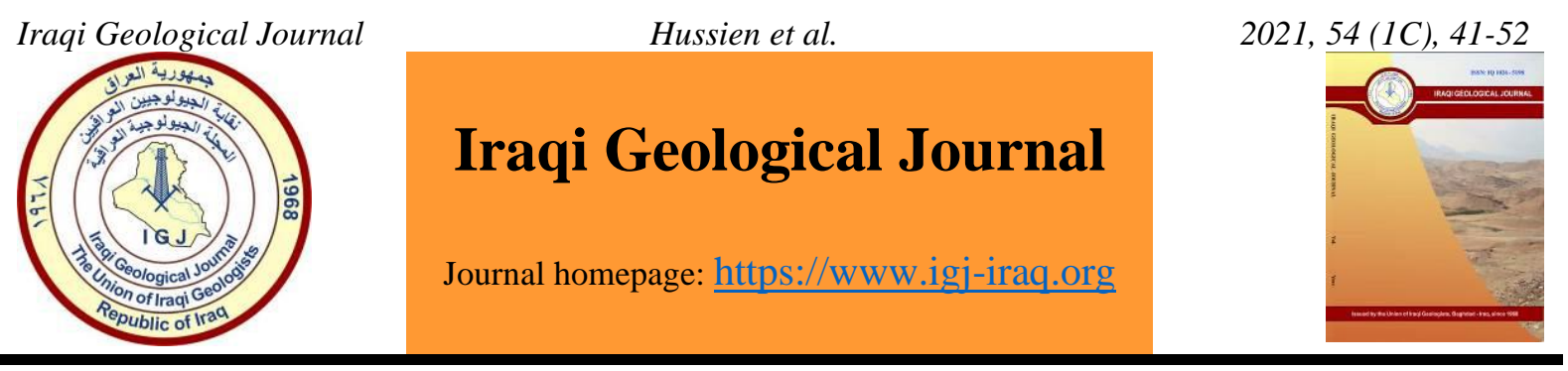

\title{
Geochemical Study of Injana Formation and its Tectonic Significances in Selected Areas, Iraq
}

\author{
Mohammed L. Hussien ${ }^{1}$, Linaz Anis Fadhil ${ }^{2}$ and Ahmed Abbas Hasan ${ }^{2}$ * \\ ${ }^{1}$ Department of Building and Construction Engineering Technologies, Al-Mustaqbal University College, Iraq \\ 2, Department of Remote Sensing, College of Remote Sensing and Geophysics, AlKarkh University of Science, Iraq. \\ * Correspondence: mlh960960@gmail.om
}

Received:8 October 2020; Accepted: 2 January 2021; Published : 31 March 2021

\begin{abstract}
This study is concerned with the geochemical analysis of major oxides; $\mathrm{SiO}_{2}, \mathrm{CaO}, \mathrm{MgO}, \mathrm{Fe}_{2} \mathrm{O}_{3}, \mathrm{Al}_{2} \mathrm{O}_{3}, \mathrm{Na}_{2} \mathrm{O}$, $\mathrm{K}_{2} \mathrm{O}, \mathrm{TiO}_{2}$, and $\mathrm{MnO}$. Atomic Absorption Spectrophotometer and Ultra Violet Spectrophotometer tools were used to examine ten samples that represented the detritus sediments of the Injana Formation in Iraq in two sites from Dohuk and Al-Najaf Governorates; where five samples for each site were collected. The chemical results emphasize that Injana sandstone is classified as litharenite to slightly sublitharenite and greywacke referring to immature clasts. Arid paleoclimtic conditions predominated during deposition of the formation which coincides with low to relatively, moderate chemical weathering. Tectonically, the studied areas represent active continental margin with a slight trend to passive margin and island arc dominated by mafic to intermediate source rocks. The provenance of the Injana Formation that had been deduced is the Tourus-Complex Zagros Mountains that are characterized by the ophiolitic-radiolaritic and complex igneous rocks.
\end{abstract}

Keywords: Geochemical study; Injana Formation; Sandstone; Tectonic significances, Iraq

\section{Introduction}

Geochemical data has significant importance for the clastic sediments as an indicator of source rocks, and many characters of these sediments. The various kinds of oxides present in Injana sediments are mostly a product of weathering of parent rock material (Yong et al. 2012). The Injana Formation (Late Miocene-Pliocene) has a spacious spread as exposed formation in Iraq. It was described for the first time by Bellen et. al. (1959). It was formerly known as the Upper Fars Formation. The name of the Injana Formation was offered by Jassim et al. (1984), which was adopted by geologists of GEOSURV, and was nominated Injana Formation by Al- Rawi, et al. (1992). According to its stratigraphic setting, the age of this formation is reported as Late Miocene (Bellen et al., 1959). The Injana Formation extends to Iran as the Agha Jari Formation (Buday, 1973), it correlates with Siirt Series in Turkey (Brinkmann, 1976; Buday, 1980), and in Syria, the Upper Fars name is used for the formation (Ejel and Abdul Rahim, 1974). The type section is near Injana area at about $120 \mathrm{~km} \mathrm{NE}$ of Baghdad toward the southern part of Hemrin Mountain, with a total thickness of $620 \mathrm{~m}$. along Tar Al-Najaf particularly near the junction with and Tar Al-Sayyed where the piping is clear, the upper part of the Formation can divide into two beds (Hassan and Al-Khateeb, 2005). Generally, the Injana Formation represents a fluviatile environment of detrital sediments as cyclotherm fining upward deposits (Basi,1973). These sediments consist of sandstone well beds which are grey to reddish brown in color, very fine to very coarse in grain

DOI: 10.46717/igj.54.1C.4Ms-2021-03-24 
size, hard to friable in hardness and massive to laminated layers in thickness. Sandstone, generally interbedded with brown and grey mudstone beds (Jawad Ali et al. 1988). General geological survey, sedimentology, provenance, environment and other investigations had been studied by many authors such as; Al-Rawi et. al. (1987); Al-Kurukji (1989); Al-Baidary (1997); Al-Bassam and Al-Baidary (2000); Jassim and Buday (in Jassim and Goff, 2006); Al-Zubaidi (2004); Al-Juboury (2009); Awadh (2014); Awadh and Al-Ankaz (2016). Most of them focused on geological overviews of the formation and/or provided descriptions of its lithofacies, provenance, sedimentology, and depositional environments. Generally, the age of the formation is accepted as the Upper Miocene. The lower contact of the formation is mostly gradational marked by a thick anhydrite layer called as the Ao marker of the Fatha (Lower Fars) Formation (Buday, 1980), while the upper boundary is gradual and typically indicated at Dohuk by the first pebbly bed of Mukdadia (Lower Bakhtiari) Formation and at Al-Najaf Dibdibba Formation. The upper boundary is gradual and typically indicated at Dohuk by the first pebbly bed of Mukdadia (Lower Bakhtiari) Formation, and Dibdibba Formation at Al-Najaf (Bellen et al., 1959). The present work aims to shed light on the origin and source rocks of this formation by the geochemical study in two sites, those are Zawita and Tar Al-Najaf areas.

\section{Materials and Methods}

Ten sand samples were collected to study geochemical properties for the two studied sites of the Injana Formation which are S1 site at Dohuk Governorate representing high folded zone in northeastern of Iraq with latitudes $36^{\circ} 54^{\prime} 58.921^{\prime \prime} \mathrm{N}$, and longitudes $41^{\circ} 93^{\prime} 3.383^{\prime \prime} \mathrm{E}$ and S2 site at Al-Najaf Governorate representing Mesopotamian plain with latitudes $32^{\circ} 3^{\prime} 59.996^{\prime \prime} \mathrm{N}$, and longitudes $44^{\circ} 11^{\prime} 47.84^{\prime \prime}$, as clarified in Fig. 1., whereas Figs.2. and 3 show geological maps of the studied area. Five samples were selected for S1 site which was S1a, S1b, S1c, S1d and S1e and the same number for S2 site which are S2a, S2b, S2c, S2d, and S2e). The chosen samples were prepared to examine by Atomic Absorption Spectrophotometer and Ultraviolet Spectrophotometer tools in Iraqi Geological survey state to determine major oxides which are $\mathrm{SiO}_{2}, \mathrm{CaO}, \mathrm{MgO}, \mathrm{Fe}_{2} \mathrm{O}_{3}, \mathrm{Al}_{2} \mathrm{O}_{3}, \mathrm{Na}_{2} \mathrm{O}, \mathrm{K}_{2} \mathrm{O}, \mathrm{TiO}_{2}$, $\mathrm{MnO}$. After heating the sediment sample at a selected temperature, its weight has been partially, lacked resulting from the decomposition of carbonate and organic matter, moreover, the interstitial water liberating. This is represented by the loss on ignition (LOI), as illustrated in Table 1. Table 2 shows the correlation coefficient between the major oxides.

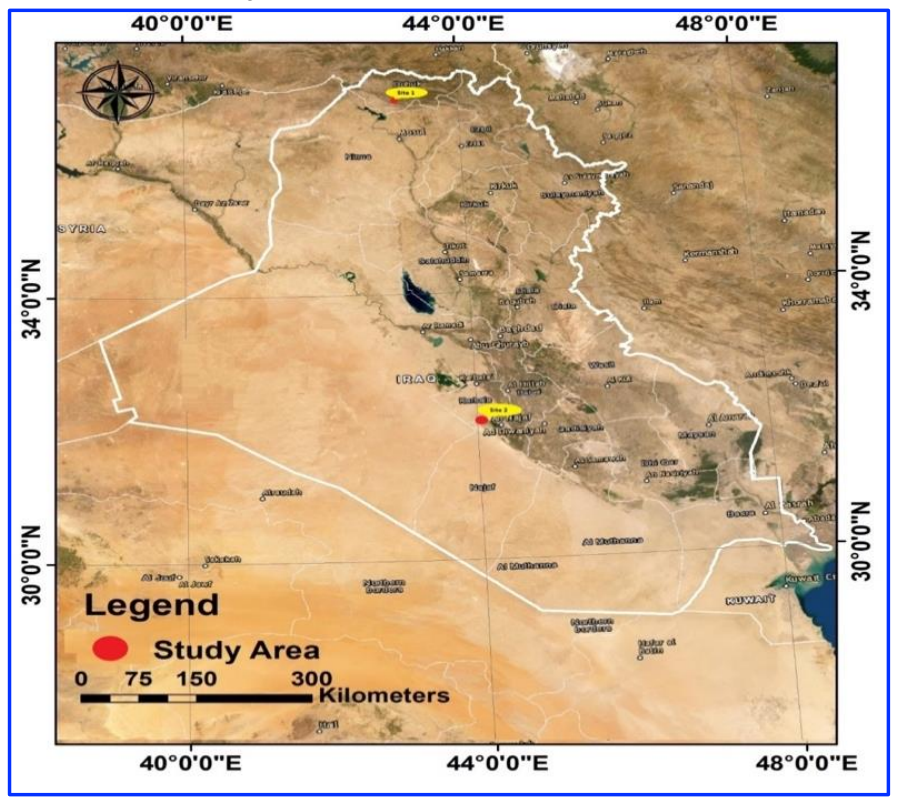

Fig. 1. Location map shows the studied sites 


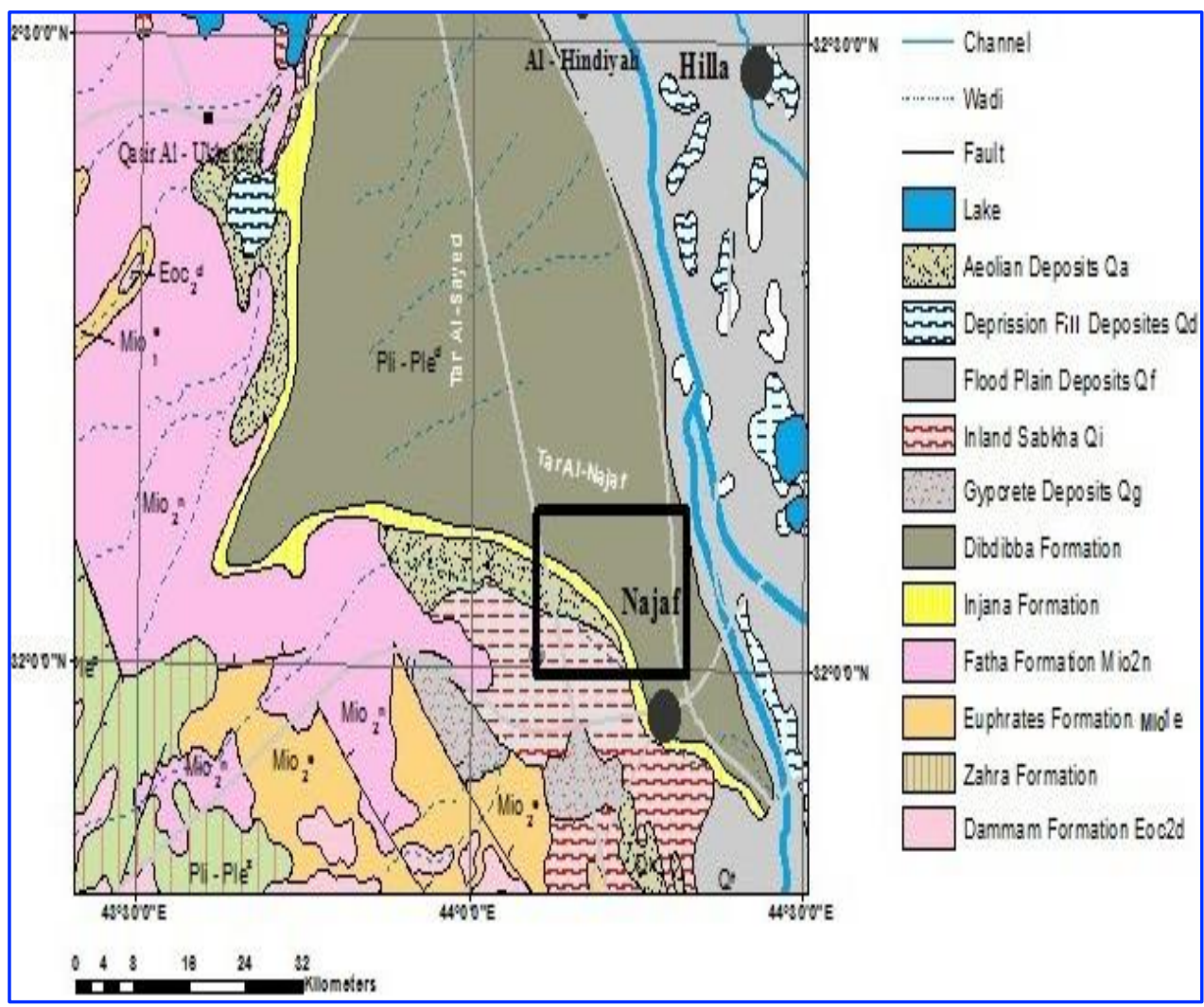

Fig. 2. Geological map of Al-Najaf area shows studied site (sheet NH 38-2, Iraq geological survey, 1996)

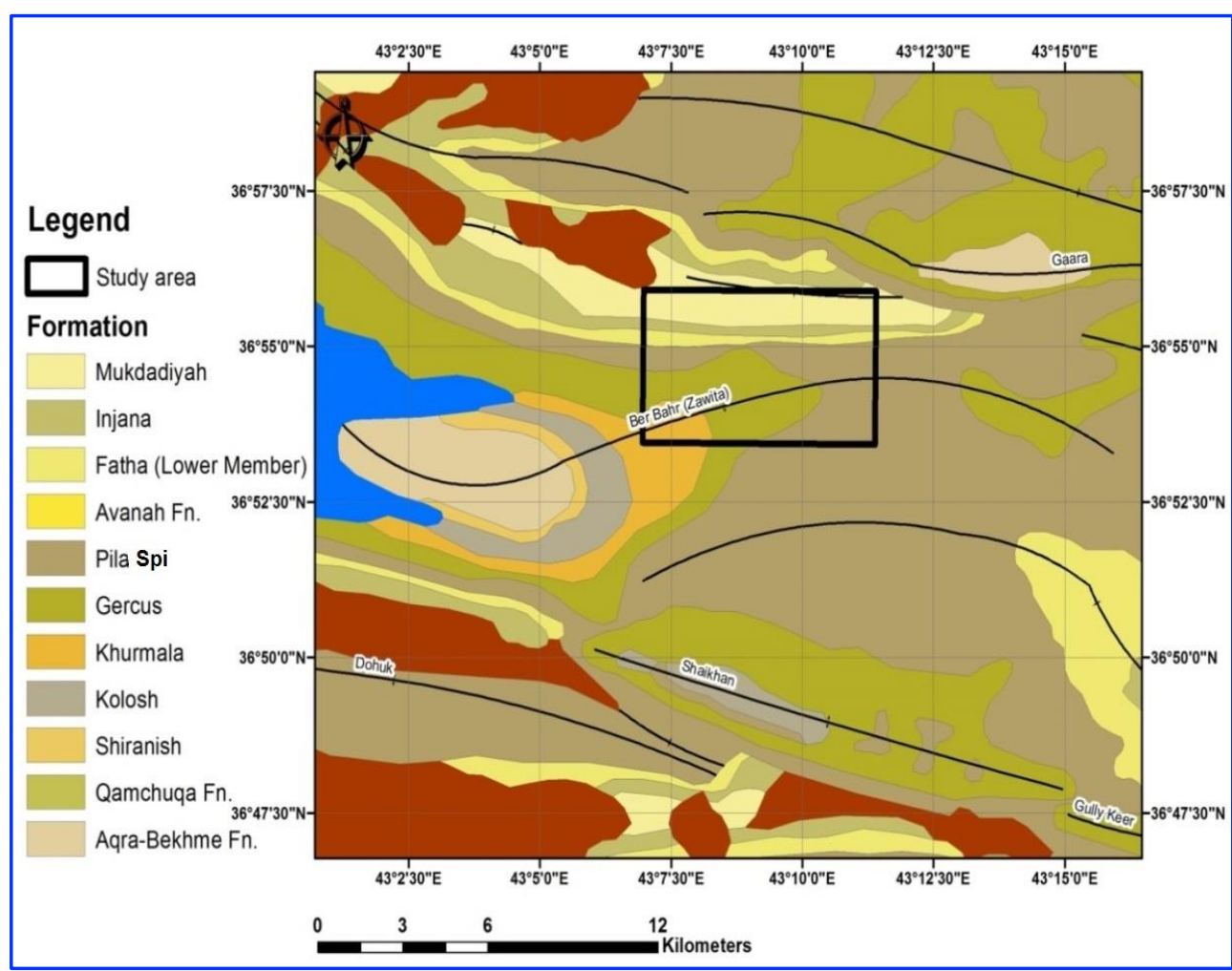

Fig. 3. Geological map of Dohuk area shows studied site (sheet NJ 38-13, Iraq geological survey, 2008) 
Table 1. Geochemical analysis of major oxides for the Injana Formation sediments

\begin{tabular}{|c|c|c|c|c|c|c|c|c|c|c|c|c|c|}
\hline Sample & $\mathrm{SiO}_{2}$ & $\mathrm{Fe}_{2} \mathrm{O}_{3}$ & $\mathrm{Al}_{2} \mathrm{O}_{3}$ & $\mathrm{CaO}$ & MgO & $\mathrm{Na}_{2} \mathrm{O}$ & $\mathrm{K}_{2} \mathrm{O}$ & $\mathrm{TiO}_{2}$ & MnO & L.O.I. & Total & $\begin{array}{l}\mathrm{SiO}_{2} / \\
\mathrm{Al}_{2} \mathrm{O}_{3} \\
\end{array}$ & $\begin{array}{c}\mathrm{Al}_{2} \mathrm{O}_{3} / \\
\mathrm{TiO2} \\
\end{array}$ \\
\hline & & & & & & & $\%$ & & & & & & \\
\hline S1a & 51.9 & 6.16 & 4.14 & 10.14 & 8.18 & 2.40 & 2.16 & 0.45 & 0.10 & 14.5 & 100.2 & 12.5 & 9.2 \\
\hline S1b & 52.7 & 5.93 & 3.34 & 9.56 & 6.58 & 2.33 & 2.11 & 0.45 & 0.09 & 16.94 & 100 & 15.8 & 7.4 \\
\hline S1c & 52.4 & 8.6 & 6.19 & 9.31 & 5.74 & 1.37 & 2.32 & 0.43 & 0.04 & 13.6 & 99.8 & 8.5 & 14.4 \\
\hline S1d & 52.3 & 7.42 & 5.15 & 9.63 & 6.89 & 1.91 & 2.66 & 0.41 & 0.23 & 13.2 & 99.9 & 10.15 & 12.5 \\
\hline S1e & 51.2 & 6.81 & 6.77 & 10.43 & 6.16 & 2.11 & 2.04 & 0.38 & 0.19 & 14.1 & 100.2 & 7.56 & 17.8 \\
\hline $\mathrm{S} 2 \mathrm{a}$ & 38.8 & 4.76 & 7.85 & 11.96 & 10.7 & 2.10 & 1.75 & 0.28 & 0.07 & 20.6 & 99.9 & 4.94 & 28.0 \\
\hline $\mathrm{S} 2 \mathrm{~b}$ & 45.9 & 3.05 & 6.73 & 12.15 & 8.2 & 2.9 & 1.49 & 0.28 & 0.06 & 15.9 & 100 & 6.82 & 24.0 \\
\hline $\mathrm{S} 2 \mathrm{c}$ & 35.9 & 4.3 & 7.8 & 10.8 & 11.3 & 3.70 & 1.55 & 0.29 & 0.04 & 23.9 & 99.9 & 4.60 & 26.9 \\
\hline S2d & 43.7 & 6.78 & 4.90 & 12.94 & 6.14 & 1.6 & 2.55 & 0.33 & 0.05 & 20.9 & 99.9 & 8.91 & 14.8 \\
\hline $\mathrm{S} 2 \mathrm{e}$ & 49.2 & 3.92 & 3.66 & 11.11 & 6.99 & 3.04 & 2.59 & 0.30 & 0.04 & 22.7 & 99.7 & 13.44 & 12.2 \\
\hline Max. & 52.7 & 8.6 & 7.85 & 12.94 & 11.3 & 3.70 & 2.66 & 0.45 & 0.23 & 23.9 & 100.2 & 15.77 & 28.0 \\
\hline Min. & 35.9 & 3.05 & 3.34 & 9.31 & 5.58 & 1.37 & 1.49 & 0.28 & 0.04 & 13.2 & 99.7 & 4.60 & 7.4 \\
\hline Aver. & 47.40 & 5.77 & 5.65 & 10.80 & 7.70 & 2.35 & 2.12 & 0.36 & 0.12 & 17.6 & 99.9 & 9.46 & 16.9 \\
\hline
\end{tabular}

Table 2. Correlation coefficient between major oxides in clast sediments of Injana Formation in the study areas

\begin{tabular}{lcccccccccc}
\hline & $\mathrm{SiO}_{2}$ & $\mathrm{Fe}_{2} \mathrm{O}_{3}$ & $\mathrm{Al}_{2} \mathrm{O3}$ & $\mathrm{CaO}$ & $\mathrm{MgO}$ & $\mathrm{Na}_{2} \mathrm{O}$ & $\mathrm{K2O}$ & $\mathrm{TiO}_{2}$ & $\mathrm{MnO}$ & $\mathrm{LOI}$ \\
\hline $\mathrm{SiO}_{2}$ & 1.000 & & & & & & & & & \\
$\mathrm{Fe}_{2} \mathrm{O}_{3}$ & -0.621 & 1.000 & & & & & & & & \\
$\mathrm{Al}_{2} \mathrm{O}_{3}$ & -0.729 & 0.421 & 1.000 & & & & & & & \\
$\mathbf{C a O}$ & -0.184 & 0.284 & 0.444 & 1.000 & & & & & & \\
$\mathbf{M g O}$ & 0.565 & -0.283 & -0.508 & -0.537 & 1.000 & & & & & \\
$\mathbf{N a}_{2} \mathrm{O}$ & 0.550 & -0.277 & -0.570 & -0.703 & 0.636 & 1.000 & & & & \\
$\mathbf{K}_{2} \mathrm{O}$ & -0.362 & 0.724 & 0.215 & 0.443 & -0.215 & -0.135 & 1.000 & & & \\
$\mathrm{TiO}_{2}$ & 0.150 & -0.055 & -0.544 & -0.680 & 0.146 & 0.591 & -0.097 & 1.000 & & \\
$\mathbf{M n O}$ & -0.593 & 0.408 & 0.746 & 0.589 & -0.821 & -0.612 & 0.316 & -0.174 & 1.000 & \\
$\mathbf{L O I}$ & -0.779 & 0.465 & 0.803 & 0.576 & -0.466 & -0.817 & 0.257 & -0.666 & 0.539 & 1.000 \\
\hline
\end{tabular}

\section{Results and Discussion}

The percentage of major oxides are explained in Table 1, where the chemical composition of investigated samples can be described as below:

\section{1. $\mathrm{SiO}_{2}$}

$\mathrm{SiO}_{2}$ represented the prevalent constituent among other contents ranging from $35.9 \%$ to $52.7 \%$ with an average of $47.4 \%$ (Table 1). The main origin of silica is derived mainly from detrital quartz, chert, feldspar fragments, and heavy minerals. The silica values in S1 site are higher than in S2 site reflecting the high silica abundant in Dohuk compare to Al-Najaf areas. The enrichment of quartz is an indication of sandstone maturity, due to its resistance to weathering and destruction for long transportation (Obiefuna and Orazulike, 2011). $\mathrm{SiO}_{2}$ has strong negative correlation coefficient with each of $\mathrm{Al}_{2} \mathrm{O}_{3}$, $\mathrm{Fe}_{2} \mathrm{O}_{3}, \mathrm{MnO}$ and LOI (Table 2); that indicates silica is found as independent mineral (quartz) and has not correlated with other oxides, moreover it confirms the maturity of sandstone. $\mathrm{MgO}$ has positive sign with $\mathrm{Na}_{2} \mathrm{O}$ according to the geochemical behavior

\section{2. $\mathrm{Al}_{2} \mathrm{O}_{3}$}

Alumina concentration is restricted between $3.34 \%$ and $7.85 \%$ with an average of $5.65 \%$. Clay minerals are the main source of $\mathrm{Al}_{2} \mathrm{O}_{3}$. The Ruxton ratio $\left(\mathrm{SiO}_{2} / \mathrm{Al}_{2} \mathrm{O}_{3}\right)$ proposed by Ruxton (1968) reflects the weathering action and multiple sedimentary cycles; furthermore, it is considered an indication of sediments maturity. The high average value of this ratio (28.4) for the sandstone hints enrichment in quartz and also reflects quartz arenite sand, the low ratios represent chemically, immature sediments (Roser et al. 1996). The Injana Formation in the studied area has a relatively, low-value ratio 
which is 9.46 reflecting chemically, immature sediments (Table 1). $\mathrm{Al}_{2} \mathrm{O}_{3}$ is recognized with a significant positive correlation coefficient related to $\mathrm{MnO}$ and LOI reflecting the similarity in the geochemical behavior (Table 1).

\section{3. $\mathrm{TiO}_{2}$}

Titania has low concentration ranging from $0.28 \%$ to $0.45 \%$ with an average of $0.36 \%$. Several types of ratios can be utilized to detect the synthesis of source rocks; one of them which is the $\mathrm{Al}_{2} \mathrm{O}_{3} / \mathrm{TiO}_{2}$ against $\mathrm{SiO}_{2}$ to be plotted as diagram (Nagarajan et al. 2007). The plot diagram refers to mafic extending to intermediate source rocks as in Fig. 4. Heavy minerals, especially rutile, titanite, and ilmenite are the main original source. Titania has weak correlation coefficient with other oxides that back to its low presence in the studied samples.

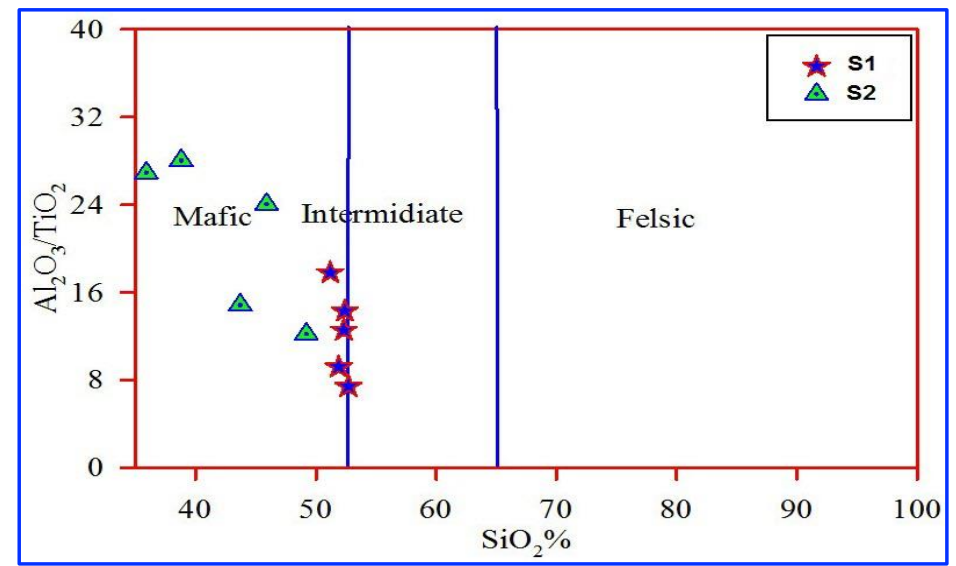

Fig. 4. $\mathrm{Al}_{2} \mathrm{O}_{3} / \mathrm{TiO}_{2}$ versus $\mathrm{SiO}_{2}$ bivariate plot displays the nature of mafic to slightly intermediate source rocks of Injana clasts after Le Bas et al. (1986)

\section{4. $\mathrm{CaO}$}

The distribution of $\mathrm{CaO}$ in the Injana Formation is districted between $9.31 \%$ to $12.94 \%$ with an average of $10.80 \%$ reflecting a homogeneity of cementation, and carbonate rock fragments. Farquhar et al. (2015) suggested certain limits for sand cements due to $\mathrm{CaO}$ contents; those are: $\mathrm{CaO}<4 \%$ for noncalcareous; $4 \%<\mathrm{CaO}<15 \%$ for calcareous; and $\mathrm{CaO}>15 \%$ for carbonate. Consequently, the studied sediments are calcareous. Carbonate as cement material or fragments, anorthite feldspar, pyroxene, and amphibole are the main sources for $\mathrm{CaO}$. Strong negative correlation coefficient characterizes $\mathrm{CaO}$ with $\mathrm{Na}_{2} \mathrm{O}$ and $\mathrm{TiO}_{2}$ belongs to variation in their geochemical behavior.

\subsection{MgO}

Magnesia is related mostly to the presence of ferromagnesian minerals, dolomite which occurs as fragments or cement, several types of heavy minerals, montmorillonite and mixed layer smectite. The quantity of $\mathrm{MgO}$ ranges from $5.58 \%$ to $11.3 \%$ with a mean of $7.7 \%$. Magnesia records strong positive correlation coefficient with $\mathrm{Na}_{2} \mathrm{O}$ indicating to their presence in clay minerals together; and significant negative relationship with $\mathrm{MnO}$ which refers to different conditions of sedimentation.

\section{6. $\mathrm{Fe}_{2} \mathrm{O}_{3}$}

The concentration of $\mathrm{Fe}_{2} \mathrm{O}_{3}$ is restricted between $3.05 \%$ to $8.6 \%$ with an average of $5.77 \%$. It refers to presence ferromagnesian minerals, heavy minerals as opaque constituents, or may back to absorbed on clay minerals surface or combined with $\mathrm{S}$ to form $\left(\mathrm{FeS}_{2}\right)$ pyrite mineral (Veld and Meunier, 2008). The variation in geochemical behavior between silica and iron results in a negative correlation 
between them $(\mathrm{r}=-0.62)$. The movement of silica increase in basic solution, while the movement of iron increase in acidic solution.

\section{7. $\mathrm{K}_{2} \mathrm{O}$}

Potassium feldspars (orthoclase and microcline), mica minerals (muscovite) and clay minerals like illite may be source of potassium oxide. The concentration of it ranges from $1.49 \%$ to $2.66 \%$ with an average of $2.12 \%$. Statistically, the positive correlation between $\mathrm{Fe}_{2} \mathrm{O}_{3}$ and $\mathrm{K}_{2} \mathrm{O}$ as shown in Table 2 $(\mathrm{r}=0.74)$ indicates their association with clay minerals, where $\mathrm{Fe}_{2} \mathrm{O}_{3}$ was adsorbed on the clay mineral surfaces.

\section{8. $\mathrm{Na}_{2} \mathrm{O}$}

The content of $\mathrm{Na}_{2} \mathrm{O}$ is restricted between $1.37 \%$ and $3.70 \%$ with an average of $2.35 \%$. This narrow range of distribution refers to the homogeneity of albite feldspar in Injana Formation; also, $\mathrm{Na}_{2} \mathrm{O}$ content is principally, related to clay minerals and it significantly, correlates with $\mathrm{K}_{2} \mathrm{O}$. The depletion of $\mathrm{Na}_{2} \mathrm{O}$ and $\mathrm{K}_{2} \mathrm{O}$ can be attributed to the modification of feldspars in the source region or during transportation (Tobia and Aswad, 2015). The geochemical classification of the Injana Formation in the studied sites depends on the diagram proposed by Herron (1988) to classify terrigenous sediments using scatter plots of $\log \left(\mathrm{Fe}_{2} \mathrm{O}_{3} / \mathrm{K}_{2} \mathrm{O}\right)$ versus $\log \left(\mathrm{SiO}_{2} / \mathrm{Al}_{2} \mathrm{O}_{3}\right)$. Accordingly, the studied sediments are classified as litharenite to sublitharenite with relative grade to gray wake as clarified in fig. 5 . The observed variation is attributed to the multi-source.

\section{9. $\mathrm{MnO}$}

Manganese amount is the minor constituent which ranges from $0.04 \%$ to $0.23 \%$ with an average of $0.12 \%$, that reflects the minority of manganese in the studied area. In spite of the scarcity of $\mathrm{MnO}$, but there is a variable correlation with other oxides indicating the different sources.

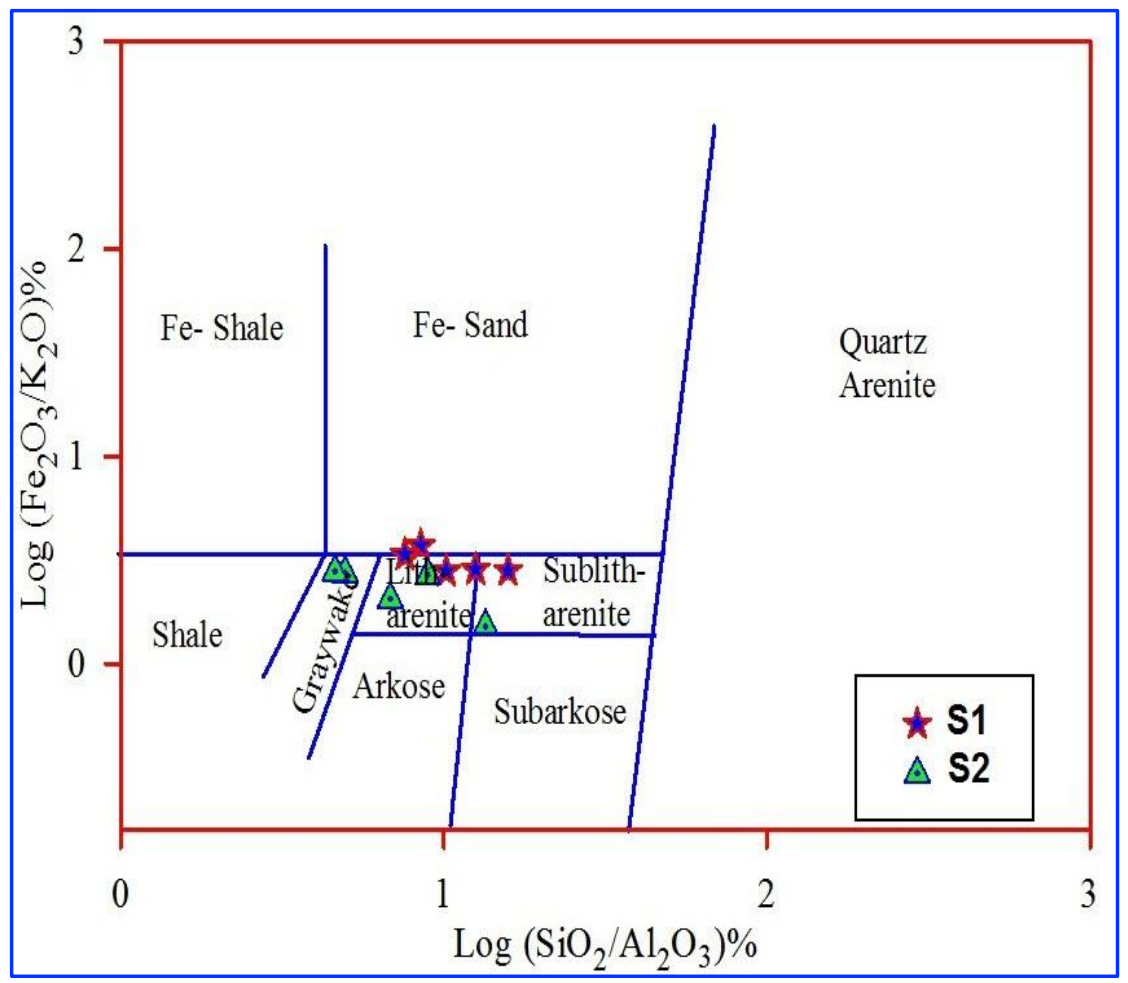

Fig. 5. The $\log \left(\mathrm{SiO}_{2} / \mathrm{Al}_{2} \mathrm{O}_{3}\right)$ vs. $\log \left(\mathrm{Fe}_{2} \mathrm{O}_{3} / \mathrm{K}_{2} \mathrm{O}\right)$ plot to determine the geochemical classification of Injana Formation after Herron (1988) 


\subsection{LOI}

LOI ranges between $13.2 \%$ and $23.9 \%$ with an average of $17.6 \%$. It has a positive correlation with $\mathrm{CaO}$ which is reflected in the content of $\mathrm{CO}_{2}$. The positive correlation between LOI with $\mathrm{Al}_{2} \mathrm{O}$ and $\mathrm{K}_{2} \mathrm{O}$ indicates that they are mainly associated with clay minerals (Table 2). The significant negative correlation between $\mathrm{LOI}$ with $\mathrm{SiO}_{2}$ and $\mathrm{TiO}_{2}$ reflects that $\mathrm{LOI}$ is not associated with the resistant oxides.

\subsection{Chemical Weathering}

The mineralogical and geochemical characteristics of sedimentary rocks have been influenced, strongly by the intensity of chemical weathering (Mongelli et al. 2006). Nesbitt and Young (1982) proposed the chemical index of alteration (CIA), which was the common weathering and alteration indicator for the source area, calculated by the formula (Nesbitt and Young, 1982):

$$
\mathrm{CIA}=\left[\mathrm{Al}_{2} \mathrm{O}_{3} /\left(\mathrm{Al}_{2} \mathrm{O}_{3}+\mathrm{CaO}^{*}+\mathrm{Na}_{2} \mathrm{O}+\mathrm{K}_{2} \mathrm{O}\right)\right] \times 100 .
$$

Where the oxides are expressed as molar proportions and $\mathrm{CaO}^{*}$ merely refers to the $\mathrm{Ca}$ incorporated only in silicate fraction (Baiyegunhi et al., 2017). Honda and Shimizu (1998) provided the following formula to correct $\mathrm{CaO}^{*}$.

$$
\mathrm{CaO}^{*}=0.35 * 2\left(\mathrm{Na}_{2} \mathrm{O} \%\right) / 62
$$

To remove the impact of post- carbonaceous leaching, an assumption was adopted; accordingly, the $\mathrm{CaO}$ represents the mole fraction of remnant $\mathrm{CaO}$ after removing $\mathrm{CaO} *$ from apatite (Bock et al. 1998). In the case of $\mathrm{CaO}$ equal or less than $\mathrm{Na}_{2} \mathrm{O}$, then the value of $\mathrm{CaO}$ is acceptable; whereas, if $\mathrm{CaO}$ more than $\mathrm{Na}_{2} \mathrm{O}$, then $\mathrm{CaO}^{*}$ equal to $\mathrm{Na}_{2} \mathrm{O}$. Consequently, all $\mathrm{CaO}^{*}$ was considered as silica fraction due to the low content of carbonate in the Injana Formation. The number of mobile cations such as $\mathrm{K}^{+}$, $\mathrm{Na}^{+}$, and $\mathrm{Ca}^{2+}$, in addition to the less mobile cations such as $\mathrm{Al}^{3+}$ which remains steady in the weathering residue that is present in the samples may be determined by using this index (CIA).

The significant rising elimination of $\mathrm{K}, \mathrm{Ca}$, and $\mathrm{Na}$ cations compare to the more stable $\mathrm{Al}^{3+}$ back to high CIA values, and these consequently, refer to the weathering intensity (Concepcion et al. 2011). Therefore, the consumption of alkalis and alkaline earth elements and preferential enrichment of $\mathrm{Al}_{2} \mathrm{O}_{3}$ may be produced by the alteration of rocks during weathering (Baruah et al. 2017). CIA is also much affected by grain size. It increases as grain size decreases (Oni and Olatunji, 2017).

The CIA values range between 45 and 100 in case of fresh rocks and completely weathered rocks respectively. Wherefore CIA values between 45- 55 denote absent chemical weathering and indicate to cool and/or arid climatic conditions (Fedo et al. 1995). CIA $\geq 60$ infer low chemical weathering, between 60-80 imply very little- moderate chemical alteration, whereas those that are more than 80 refer to high intensity of chemical weathering (Sang et al., 2018). The CIA values of the Injana sediments in the studied sites are ranging from 31.1 to 59.1 with an average of 46.5 indicating absent to low chemical weathering.

The clastic sediments of the Injana Formation are plotted in A-CN-K diagram, where $\mathrm{A}=\mathrm{Al}_{2} \mathrm{O}_{3}$, $\mathrm{CN}=\mathrm{CaO}+\mathrm{Na}_{2} \mathrm{O}$, and $\mathrm{K}=\mathrm{K}_{2} \mathrm{O}$, as in fig.6. Investigated sediment samples were plotted on the CIA versus $\mathrm{Al}_{2} \mathrm{O}_{3}$ diagram (Obasi and Madukwe, 2016), which confirms that most of the samples were affected by low to absent weathering, while few of them were affected by moderate weathering, as in Figs.6 and 7. 


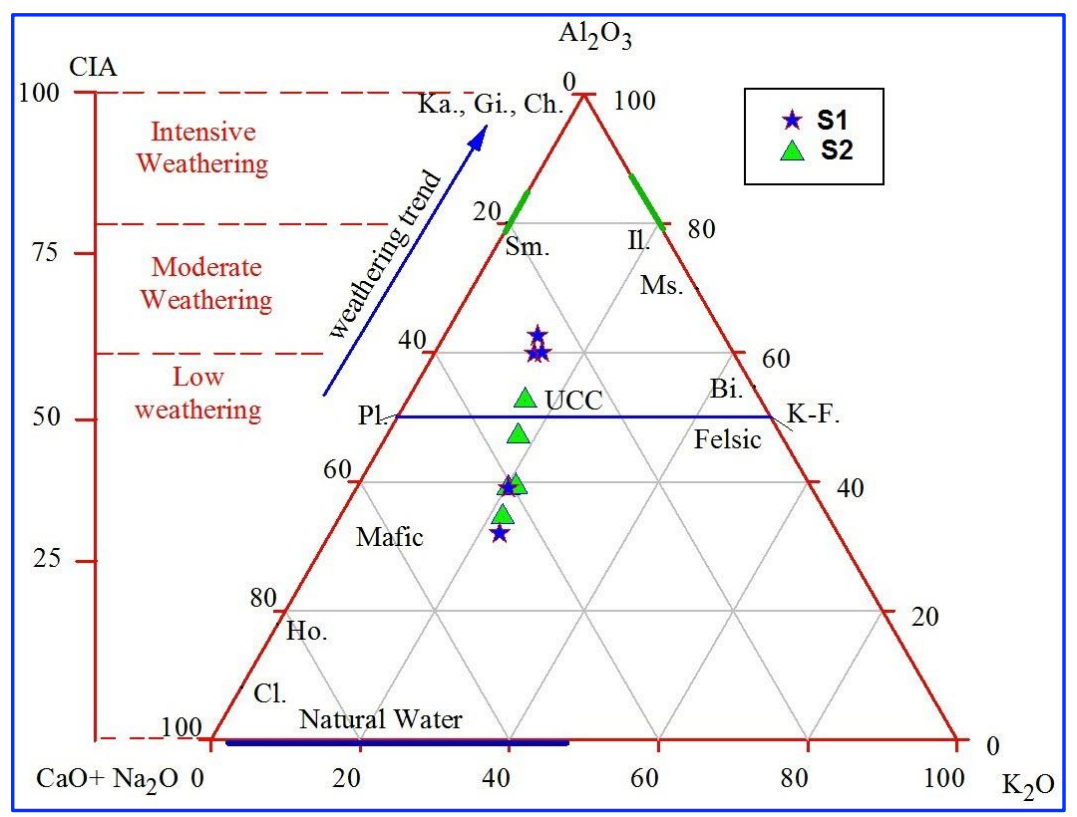

Fig. 6. Illustrates A-CN-K ternary diagram for the clastic rocks of Injana Formation; Ka: kaolinite; Gi:gibbsite; Ch:chlorite; Sm:smectite; Il:illite; Ms:muscovite; Bi: biotite; Pl: plagioclase; K-F: K-feldspar; Cl:clinopyroxene;

Ho:hornblende. $\mathrm{CN}$ : $\mathrm{CaO}+\mathrm{Na}_{2} \mathrm{O} ; \mathrm{K}: \mathrm{K}_{2} \mathrm{O} ; \mathrm{A}: \mathrm{Al}_{2} \mathrm{O}$. UCC: upper continental crust. Fields after Nesbitt and Young (1982)

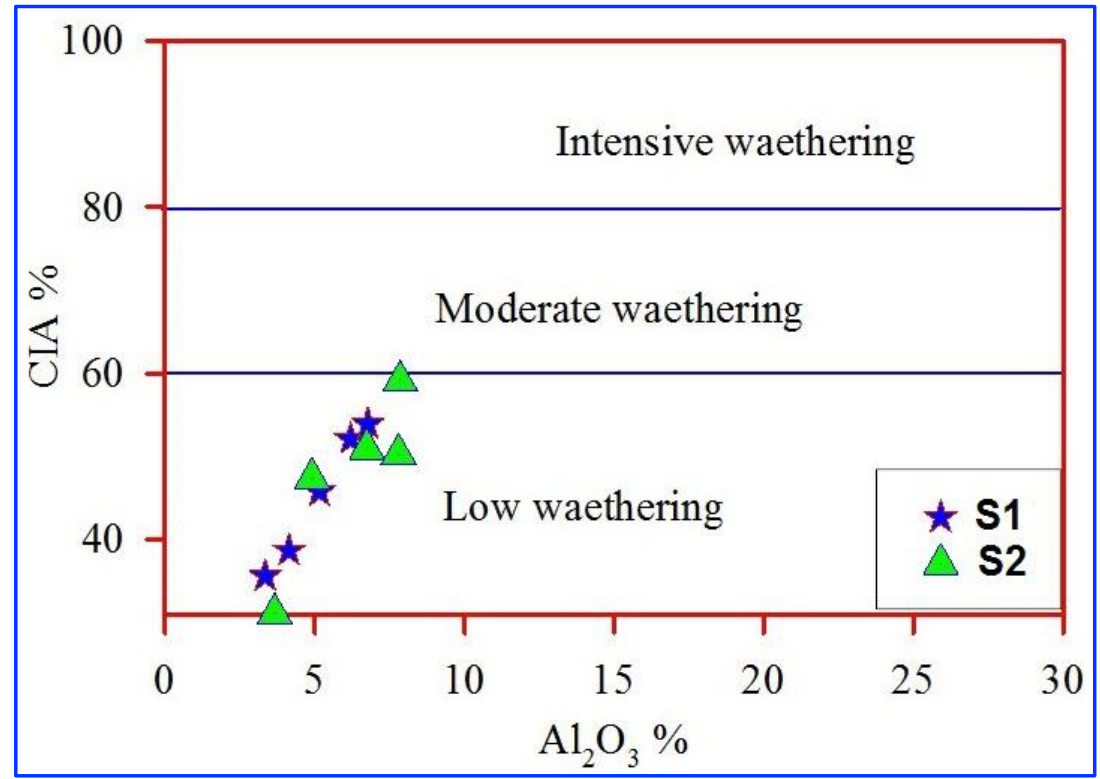

Fig. 7. CIA vs $\mathrm{Al}_{2} \mathrm{O}_{3}$ diagram for the chemical weathering of the studied sediment rocks of the Injana Formation after Obasi and Madukwe (2016)

\subsection{Maturity and Paleoclimate}

The chemical maturity identification as a function of paleoclimate has been expressed by utilizing the bivariant diagram of $\mathrm{SiO}_{2}$ against $\mathrm{Al}_{2} \mathrm{O}_{3}+\mathrm{K}_{2} \mathrm{O}+\mathrm{Na}_{2} \mathrm{O}$ proposed by Suttner and Dutta (1986). $\mathrm{SiO}_{2}$ reflects the quartz content, whilst $\mathrm{Al}_{2} \mathrm{O}_{3}+\mathrm{K}_{2} \mathrm{O}+\mathrm{Na}_{2} \mathrm{O}$ refers to the feldspar content (Malick and Ishiga, 2016). The investigated samples of Injana sandstones in this plot represent an arid climatic condition coincide with low to moderate chemical maturity, as shown in fig. 8, that generally, is linked with relatively low chemical weathering (Nesbitt and Young, 1982). 


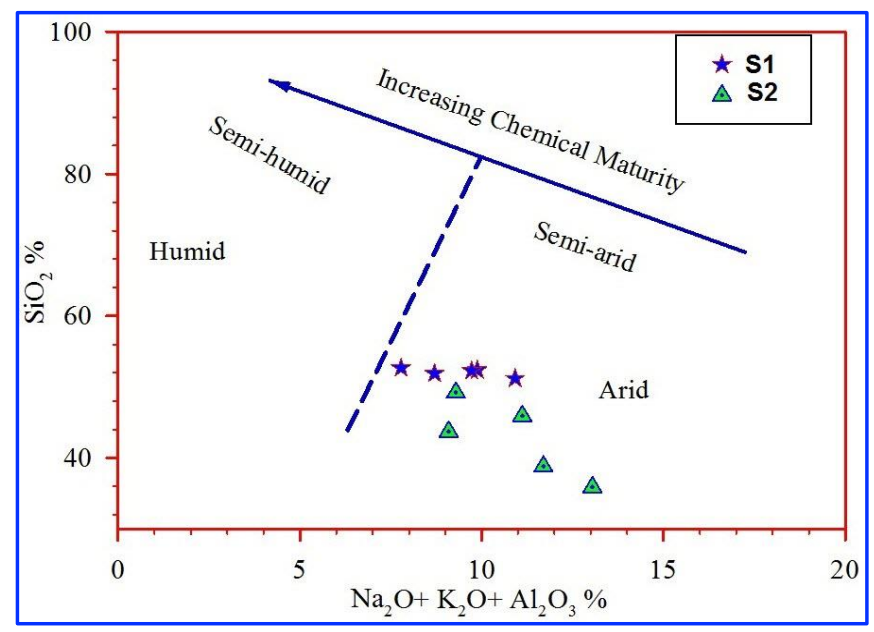

Fig. 8. Bivariant plot $\mathrm{SiO}_{2}$ versus $\mathrm{Al}_{2} \mathrm{O}_{3}+\mathrm{K}_{2} \mathrm{O}+\mathrm{Na}_{2} \mathrm{O}$ shows paleoclimatic conditions and chemical maturity of Injana Formation rocks after Suttner and Dutta, (1986)

\subsection{Provenance and Tectonic Setting}

Plate tectonic settings of the depositional basin had controlled considerably, by the chemical compositions of siliciclastic sedimentary rocks (Bhatia and Crook, 1986). Consequently, geochemical discrimination parameters have a certain interest in determining provenance and tectonic settings of terrigenous sedimentary rocks. Concepcion et al. (2011) established the tectonic setting of clastic sediment suites by using major oxides such as $\mathrm{K}_{2} \mathrm{O}, \mathrm{Na}_{2} \mathrm{O}$ as $\log$ versus $\mathrm{SiO}_{2}$. Producing from this diagram clarify that Injana Formation sandstones fall in the active continental margin with slightly extending to passive margin at the S1 site, and with more trend to the island arc at S2 site as in Fig. 9. Moreover, they occupy mafic to relatively intermediate fields as in Fig. 4. Al-Rawi et al. (1992) reported that the tectonic setting of the northeastern region of Iraq was the active high land coincided with the incidence of subduction and collision of Arabian and Iranian plates. In conclusion, the ophiolites, the radiolarite, and the complex igneous rocks, beside the sediments derived from the recycling of older sedimentary formation were the source rocks of Injana Formation sediments. Mafic and ultramafic ophiolite had a significant contribution as source rocks. Complex Zagros-Taurus Mountains which were formed, tectonically by the highly folded and thrust Nappe Zone of north and northeastern Iraq (AlJuboury, 2009) was the provenance of the Injana Formation sediments in the studied areas.

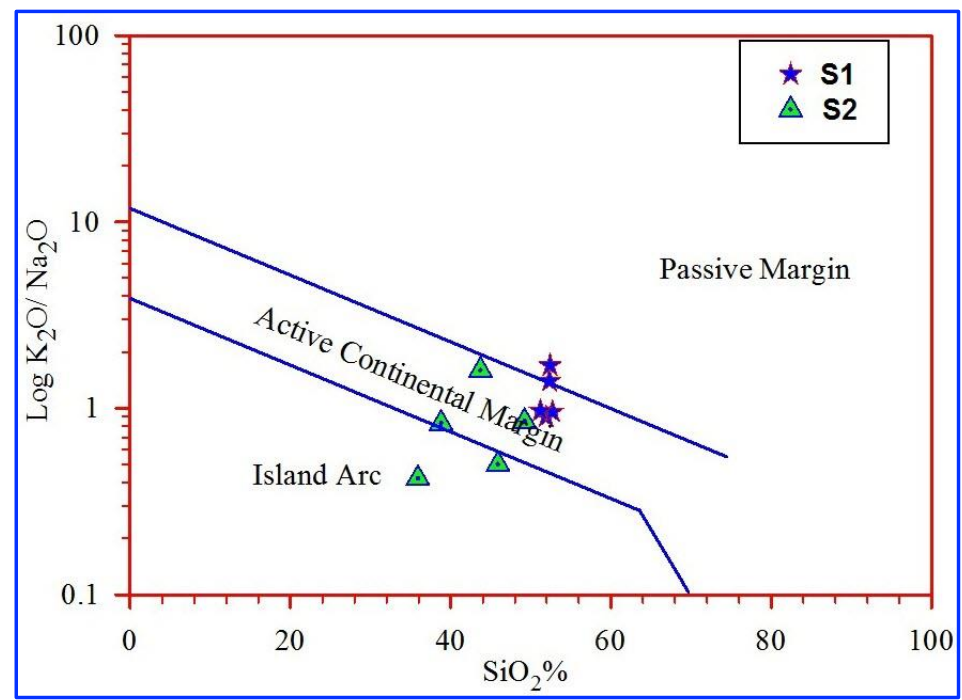

Fig. 9. Scatter plot of $\mathrm{SiO}_{2}$ vs. $\log \left(\mathrm{K}_{2} \mathrm{O} / \mathrm{Na}_{2} \mathrm{O}\right)$ for clastic sediments explains the tectonic setting of Injana Formation adopted by Roser and Korsch (1986) 


\section{Conclusions}

Chemical investigation of major oxides which are $\mathrm{SiO}_{2}, \mathrm{CaO}, \mathrm{MgO}, \mathrm{Fe}_{2} \mathrm{O}_{3}, \mathrm{Al}_{2} \mathrm{O}_{3}, \mathrm{Na}_{2} \mathrm{O}, \mathrm{K}_{2} \mathrm{O}$, $\mathrm{TiO}_{2}, \mathrm{MnO}$, in addition to LOI for the Injana Formation in Dohuk and Al-Najaf Governorates demonstrates the following:

1. Statistically, the major oxides exhibit different relationships of correlation coefficient reflecting various sediment constituents and their origin and sedimentary conditions.

2. The clastic sediments are classified as litharenite to sublitharenite with slightly trending to greywacke; therefore, the sandstones are immature.

3. Low chemical weathering with relatively grade to moderate weathering recognize the Injana clasts indicating to arid paleoclimatic conditions.

4. Tectonically, the studied areas represent active continental margin and partially, passive continental margin at Dohuk and island arc at Al-Najaf areas. Mafic with a limit contribution of intermediate source rocks characterize those sediments.

5. In general, the ophiolite and radiolarite successions from the active upland in the north and northeastern Iraq that reflected the contribution of the mafic and ultramafic ophiolite, as well as recycling from older sedimentary formations considered the source rocks of the studied sediments. Complex Zagros Mountains that were originated, tectonically by the action of highly folded and thrust Nappe Zone of north and northeastern Iraq were the provenance of Injana clasts.

\section{Acknowledgements}

1 would like to thank Chairman and Editoria Board, and staff of the journal. Thanks giving and appreciation for Dr. Muhannad Rasim for his support in computerized work and other services. The authors are very grateful to the Editor in Chief Prof. Dr. Salih M. Awadh, the Secretary of Journal Mr. Samir R. Hijab. and the Technical Editors for their great efforts and valuable comments.

\section{References}

Al-Baidari, A.P.Y., 1997. Sedimentology, geochemistry, and assessment of Injana Formation at Al-Najaf-Karbala area; Unpubl. Ph. D. Thesis, Baghdad Univer., (in Arabic).

Al-Bassam, K., Al-Baidari, A.P., 2000. Palygorskite claystone of the Injana Formation (late Miocene- Pliocene) in Najaf-Razzaza area. In a symposium held in 1997. The state Co. of Geological Survey and Mining, Baghdad-Iraq.

Al-Juboury, A. I., 2009. The upper Miocene Injana (Upper Fars) Formation of Iraq: insights on provenance history, Arabian Journal Geoscience, 2 (364), 337-361.

Al-Kurukji, W. M., 1989. Facies Analysis of Upper Fars Formation in Northern Hemren Mountain, Unpubl. M.Sc. Thesis, Baghdad Univer.

Al-Rawi, Y. T., Mohammad, K. I., 1987. Petrographic investigation of the Miocene molasses sandstone of the Upper Fars Formation in central and eastern Iraq. Journal of Science.

Al-Rawi, Y. T., Sayyab, A. S., Al-Jassim, J. A., Tamar-Agha M., Al-Sammarai, A. H. I., Karim, S. A., Basi, M. A., Hagopian, D., Hassan, K. M., Al-Mubarak, M., Al-Badri, A., Dhiab, S. H., Faris, F. M., Anwar, F., 1992. New names for some of the Middle Miocene-Pliocene formations of Iraq. (Fat ha, Injana, Mukdadiya, and Bai Hassan formations). Iraqi Geological Journal, 25, (1), 1-7.

Al-Zubaida, A. A., 2004. Mineralogical and geochemical study of rocks of Injana Formation from the selected area, Central Iraq, and assessment of utilization for ceramic industries, Ph.D. Thesis, Baghdad University, Iraq, (in Arabic).

Awadh, S. M., 2014. Stable carbon and nitrogen isotopes and elemental composition and origin of organic matter from the Neogene Euphrates, Injana and Dibdibba formations in Iraq: discrimination between marine and terrestrial environments. Geological Quarterly, 58 (4):729-736. 
Awadh, S. M., Al-Ankaz, Z. S., 2016. Geochemistry and petrology of Late Miocene-Pleistocene Dibdibba sandstone formation in south and central Iraq: implications for provenance and depositional setting. Arabian Journal Geoscience, 9, 526.

Baiyegunhi, C., Liu K., Gwavava O., 2017. Geochemistry of sandstones and shales from the Ecca Group, Karoo Super group, in the Eastern Cape Province of South Africa: Implications for provenance, weathering, and tectonic setting. Open Geosciences, 9, (1), 340-360.

Baruah, H., Lahkar, A. D., Bhagabati, B., Kar, R., Das, P.K., 2017. Geochemistry of Tikak Parbat sandstones and Tipam sandstones occurring in and around Dilli Area, Sivasagar District, Assam, India. Open Journal of Geology, 7, 1238-1267.

Basi, M. A., 1973. Geology of Injana area, Hemrin south. M.Sc. Thesis, University of Mosul, Iraq (unpublished).

Bellen, R. C., Van, Dunnington, H. V., Westzel, W., Morton, D. M., 1959. Lexique Stratigraphique International, Asia, Fasc. 10a, Iraq, centre Nat. Rech, Sci. Paris, 333p.

Bhatia, M. R., Crook, K.W., 1986. Trace element characteristics of greywackes and tectonic setting discrimination of sedimentary basins: Contributions to Mineralogy and Petrology, 92 (2):181-193.

Bock, B., McLennan, S. M., Hanson, G.N., 1998. Geochemistry and provenance of the Middle Ordovician Austin Glen Member (Normanskill Formation) and the Taconian Orogeny in New England. Sedimentology, 45, 635-655.

Brinkmann, R., 1976. Geology of Turkey. New York: Elsevier.

Buday, T., 1980. The Regional Geology of Iraq. Stratigraphy and Paleontology. Baghdad: Geological Survey and Mineralogical Investigations.

Buday, T., 1973. Problem of the boundary between platform and geosyncline in Iraq. Geological Society of Iraq, 224-260.

Concepcion, R. A., Dimalanta, C. B., Yumul, J. G., Faustino-Eslava, D. V., Queano, K. L., Tamayo, J. R., and Imai, A., 2011. Petrography, geochemistry, and tectonics of a rifted fragment of Mainland Asia: evidence from the Lasala Formation, Mindoro Island, Philippines. International Journal Earth Science.

Ejel, F., Abdul Rahim, A. H., 1974. Geology of Syria. Damascus: Dar AlFikr; (In Arabic).

Farquhar, S.M., Pearce, J.K., Dawson, G.K.W., Golab, A., Sommacal, S., Kirste, D., Biddle, D., Golding, S.D., 2015. A fresh approach to investigating CO2 storage: experimental CO2-water-rock interactions in a lowsalinity reservoir system. Chemical Geology, 399, 98-122.

Fedo, C. M., Nesbitt H. W., Young G. M., 1995. Unraveling the effects of potassium metasomatism in sedimentary rocks and paleosols, with implications for paleo weathering conditions and provenance. Geology, 23, 921924.

Hassan, K. M., Al-Khateeb, A. A., 2005. Piping in cave forming claystone Injana Formation, Karbala-Najaf area, Iraqi Geological Journal, 34-38 (1), 109-116.

Herron, M. M., 1988. Geochemical classifications of terrigenous sands and shales from a core or log data. Journal Sedimentary Petrology, 58, 820-829.

Honda, M., Shimizu, H., 1998. Geochemical, mineralogical and sediment-logical studies on the Taklimakan Desert sands. Sedimentology, 45, (6), 1125-1143.

Jassim, S. Z., Buday, T., 2006. Latest Eocene-recent megasequence AP11. Geology of Iraq. Czech Republic: Dolin and Moravian Museum, 169-184.

Jassim, S. Z., Karim, S., Basi, M. A., Al-Mubarak, M., Munir, J., 1984. Final report on the regional geological survey of Iraq, vol.3, stratigraphy, origin, Min., D.G., Geol., Surv., Min., Inv., 498 P.

Jawad Ali, A, Hadi, A, Al-Shakiry, A. 1988. Fluvio-tidal complex of the Upper Fars Formation (Upper Miocene) in Hemrin Mountains, Iraq. Iraqi Journal Science, 29.

Malick, B. M. L., Ishiga, H., 2016. Geochemical classification and determination of maturity source weathering in beach sands of Eastern San' in Coast, Tango Peninsula, and Wakasa Bay, Japan. Earth Science Research, 5 (1), 44-56.

Mongelli, G., Salvatore C., Perri, F., Sonnino, M., Perrone, V., 2006. Sedimentary recycling, provenance, and paleoweathering from chemistry and mineralogy of Mesozoic continental red bed mudrocks, Peloritani Mountains, southern Italy. Geochemistry Journal, 40, 197-209.

Nagarajan, R., Madhavaraju, J., Raghavendra N., Armstrong-Aldrin, J. S., Moutte, J., 2007. Geochemistry of Neoproterozoic shales of the Rabanpalli formation, Bhima Basin, Northern Karnataka, southern India: 
implications for provenance and paleoredox conditions. Revista Mexicana de Ciencias Geologicas, 24, 150160.

Nesbitt, H. W., Young, G. M., 1982. Early Proterozoic climates and plate motions inferred from major element chemistry of lutites. Nature Journal, 299, 715-717.

Obasi, R. A., Madukwe, H. Y., 2016. Use of geochemistry to study the provenance, tectonic setting, source-area weathering and maturity of Igarra marble, Southwest, Nigeria. American Journal of Engineering Research, 5, (6), 90-99.

Obiefuna, G.I., and Orazulike, D.M., 2011. Geochemical and mineralogical composition of Bima Sandstone Deposit, Yola Area, NE Nigeria. Research Journal of Environmental and Earth Sciences, 3(2), 95-102.

Oni, O.,Olatunji, A. S., 2017. Depositional environments signatures, maturity and source weathering of Niger Delta sediments from an oil well in southeastern Delta State, Nigeria. Eurasian, Journal of Soil Science, 20, (6), $259-274$

Roser, B. P., Korsch, R. J., 1986. Determination of tectonic setting of sandstones-mudstone suites using $\mathrm{SiO}_{2}$ content and $\mathrm{K}_{2} \mathrm{O} / \mathrm{Na}_{2} \mathrm{O}$ ratio. Journal of Geology, 94, 635-650.

Roser, B. P., Cooper, R., Nathan, S., Tulloch, A. J., 1996. Reconnaissance sandstone geochemistry, provenance and tectonic setting of the Lower Palaeozoic terranes of the West Coast and Nelson, New Zealand. New Zealand, Journal of Geology Geophysics, 39, 1-16

Ruxton, B. P., 1968. Measures of the degree of chemical weathering of rocks, Journal of Geology, 76, 518-527.

Sang, P. N., Liu, Z., Zhao, Y., Zhao, X., Pha, P. D., Van,L. H., 2018. Chemical weathering in central Vietnam from clay mineralogy and major-element geochemistry of sedimentary rocks and river sediments. Halcyon, $4(7), 1-24$.

Suttner, L. J., Dutta P. K., 1986. Alluvial sandstone composition and paleoclimate framework mineralogy. Journal of Sedimentary Petrology, 56, 329-345.

Tobia, F. H., Aswad, K. J., 2015. Petrography and geochemistry of Jurassic sandstone, Western Desert, Iraq: implications on provenance and tectonic setting. Arabian Journal Geoscience, 8, 2771-2784.

Veld, B., Meunier, A., 2008. The Origin of Clay Minerals in Soils and Weathered Rocks. Springer-Verlag Berlin Heidelberg. $426 \mathrm{P}$.

Yong, R. N., Nakano, M., Pusch, R. 2012. Environmental Soil Properties and Behavior. Taylor and Francis Group. $446 \mathrm{p}$. 